\title{
Häften återuppstår (för en lässtund), Ante Farm 1943-2020
}

\author{
ESKIL WADENSJÖ
}

Ante Farm avled i oktober 2020 efter att ha varit mycket allvarligt sjuk under några veckor. Han hade avlagt licentiatexamen i matematisk statistik vid KTH 197I och haft olika uppdrag innan han började på SOFI (Institutet för social forskning) 1974. Han hade där under de första åren dels forsknings- och utredningsuppdrag (bland annat för Nordiska ministerrådet), dels administrativa arbetsuppgifter. År 1980 påbörjade han sin forskarutbildning i nationalekonomi. Efter några års arbete disputerade han 1986 med avhandlingen $A$ Model of the Price Mechanism. Han fortsatte att forska och blev 1990 docent i nationalekonomi. Samtidigt med sin forskning hade han ett stort administrativt ansvar, bland annat under några år som biträdande föreståndare för SOFI, han undervisade också på kurser i forskarutbildningen i nationalekonomi och var i perioder tjänstledig på deltid för olika uppdrag vid Arbetsmarknadsdepartementet och Statistiska centralbyrån.

Efter att ha gått i pension fortsatte han att forska än mer intensivt än tidigare. Under 2020 har fyra artiklar av Ante Farm publicerats (två i Ekonomisk Debatt, en i International Labour Review och en i Journal of Post Keynesian Economics) och han arbetade under sin sjukdomsperiod intensivt med ytterligare artiklar. Under året har också en bok utgivits för vilken han var en av de mycket aktiva redaktörerna och därtill ensam finansiär: Lars Ekdahl, Lennart Erixon, Ante Farm, Göran Fredriksson Humlesjö och Anders Gullberg (red.), Politik och marknad. Kritiska 
studier av kapitalismens utveckling (Dialogos 2020). Han bidrog också med ett kapitel i boken, "Priser och värden i praktiken". Det handlar om grundläggande ekonomisk teori.

I sin forskning har Ante Farm framför allt kritiskt granskat just grundläggande ekonomisk teori. Han menar att den ger en förenklad och felaktig bild av hur marknaderna fungerar. Den bild teorin ger stämmer bäst in på de marknader där priset sätts genom auktioner. Men så fungerar inte prissättningen på de flesta marknader. Företagen sätter priset, ser hur mycket som efterfrågas och bestämmer då produktionsvolymen och därmed också vilken deras efterfrågan på arbetskraft blir. Analysen görs både för varumarknaden och arbetsmarknaden. I sina artiklar tar han också upp frågan om prisledarskap och om fackföreningarnas och Riksbankens olika roller. Det är mycket välskrivna artiklar. De leder till eftertanke om hur ekonomier och marknader fungerar i praktiken och de ger uppslag till såväl teoretisk som empirisk nationalekonomisk forskning.

Ante Farm har också genomfört empiriskt inriktad forskning och bidragit till att utveckla ny statistik (och då under en period haft uppdrag vid Statistiska centralbyrån). Det gäller flera olika områden av arbetsmarknadsstatistik, främst vakansstatistiken. Arbetsförmedlingen har länge publicerat statistik över antalet och sammansättningen av lediga platser. Att en plats utannonseras betyder emellertid inte att den är vakant. Ofta blir den ledig först senare - om en arbetsgivare vet att någon ska gå i pension eller lämna för annat arbete utannonseras den lediga platsen många gånger lång tid innan den blir vakant. De båda måtten antalet lediga platser och antalet vakanser kompletterar varandra och leder till bättre förståelse för hur arbetsmarknaden och ekonomin fungerar. Mer om detta återfinns bland annat i hans artikel från tidigare $\mathrm{i}$ år "Measuring the effect of matching problems on unemployment", i International Labour Review (volym I59, nr 2, s. 243-258).

Redaktörerna för den ovan nämnda boken Politik och marknad har alla varit aktiva i arbetet med tidskriften Häften för Kritiska Studier. Ante Farm var medlem av redaktionen 1970-198I och hade artiklar i den 1969, I970 och 1975. Tidskriften var ett radikalt forum som började ges ut I968 och bokredaktörerna diskuterade 2018 att femtioårsjubileet borde 
uppmärksammas. Fram till utgivningen av boken hade 2OI nummer av tidskriften publicerats.

Resultatet av arbetet med att fira de femtio åren blev alltså den i år utgivna boken, där främst tidigare medarbetare i tidskriften har bidragit med kapitel men även några utomstående. Gemensamt för bidragen är att de är välskrivna, väl argumenterade och kritiska till olika inslag i den ekonomiska och politiska utvecklingen. Ett par kapitel behandlar imperialismen. Det gäller ett kapitel av Jan Otto Andersson som ser på den långsiktiga utvecklingen från imperialism och kolonialism till framväxandet av USA:s imperium. I ett andra kapitel om imperialism behandlar Stefan de Vylder utvecklingen under de senaste decennierna och beaktar då inte bara USA:s roll utan även Kinas växande inflytande. Utvecklingen av ekonomi och politik behandlas i flera kapitel från olika infallsvinklar. Ett par kapitel analyserar utvecklingen mot nyliberalism, också inom socialdemokratin. Ett intressant bidrag är av Marta Szebehely och Gabrielle Meagher. Det handlar om vinster i välfärden och de problem de leder till. Förutom Ante Farm, granskar också Lennart Erixon och Lars Pålsson Syll i sina respektive kapitel kritiskt nationalekonomisk teori och hur den utgör grund för ekonomisk politik i bland annat Sverige. Det sista och tionde kapitlet är "Feminismens vägar och avvägar" av Yvonne Hirdman, även det en kritisk granskning. 


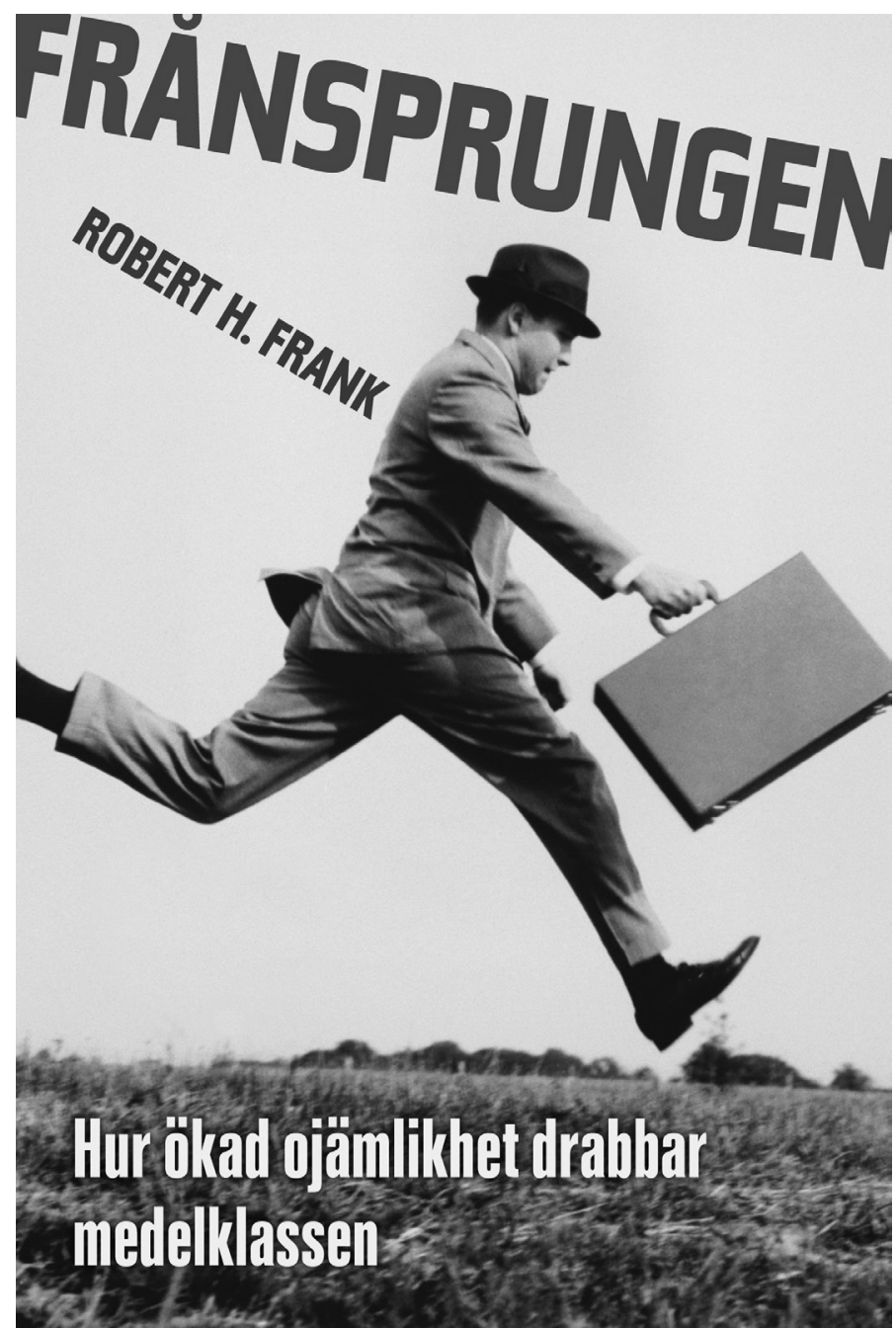

Vad sker i ett samhälle när de som redan är rika blir ännu rikare och allt mer avlägsnar sig från folkflertalet och dess villkor? I Frånsprungen visar Robert H. Frank hur den ökade ojämlikheten i USA har drivit fram en "utgiftskapprustning" där medelklassen utarmas i sina försök att hålla jämna steg med sina grannar. 